九州大学学術情報リポジトリ

Kyushu University Institutional Repository

Research Report on the Current Status and Prospects for Nineteenth-Century Ryukyuan Paintings on Wooden Doors in the Historic Miyara dunchi House

\title{
CHIE KYAN
}

Okinawa Prefectural University of Arts : Part-time lecturer

TAIRA, YŪKI

Okinawa Prefectural University of Arts : Part-time lecturer

SEIFMAN, TRAVIS (TRANSLATED BY)

https://doi.org/10.5109/4377712

出版情報: Journal of Asian Humanities at Kyushu University. 6, pp.113-127，2021-03. Kyushu University, School of Letters, Graduate School of Humanities, Faculty of Humanities バージョン:

権利関係 : 


\title{
Research Report on the Current Status and Prospects for Nineteenth-Century Ryukyuan Paintings on Wooden Doors in the Historic Miyara dunchi House
}

\author{
CHIE KYAN AND YŪKI TAIRA \\ TRANSLATED BY TRAVIS SEIFMAN
}

\section{Introduction}

$\mathbf{T}$

HIS research report examines the materials and techniques used in paintings on the wooden doors of the Miyara dunchi 宮良殿内 historic house (a nationally designated Important Cultural Property). The Miyara dunchi wooden door paintings are five wooden door paintings produced by painters in service to the Yaeyama kuramoto 八重山蔵元 ${ }^{1}$ as archi-

This research note is a slightly adapted translation of Kyan and Taira, "Kyū Miyara dunchi itadoe no genjō to tenbō," and includes revisions made by the authors. Additional footnotes have been added to the English translation. For the reader's ease of reference, the translator has indicated the original note number in brackets (e.g. [n1]) at the end of the note.

This research was made possible by a grant from the Uruma Academic Research Assistance Fund (Uruma gakujutsu kenkyū josei kikin 宇流麻学術研究助成基金). Further, in connection with the visits to the site to perform visual surveys of the works, the authors would like to express their gratitude to Miyara Yoshiaki 宮良芳明 (owner and proprietor of Miyara dunchi), Miyara Yoshikazu 宮良芳和, Miyara Yasunori 宮良安則, Shimono Eikō 下野 栄高 of the Ishigaki City Board of Education (Ishigaki-shi Kyōiku linkai 石坦市教育委員会), and the Yaeyama Museum (Yaeyama Hakubutsukan 八重山博物館). We would also like to express our gratitude to Tōma Takumi 當間巧, Shinohara Akane 篠原あかね, and everyone at the Okinawa Churashima Foundation (Okinawa Churashima Zaidan 沖縄美ら島財団) for letting us view important documents, and their kind assistance in making this research possible. tectural decoration for the Miyara dunchi.

The wooden door paintings at Miyara dunchi are extremely important materials for the study of the paintings on wood that once existed at the now-lost Engakuji 円覚寺 and Sōgenji 崇元寺 temples, Nakagusuku udun 中城御殿 Palace, and elsewhere, and for the study of the broader field of Ryukyuan painting which includes them. "Ryukyuan painting" refers to works painted during the time of the Ryukyu Kingdom (Ryūkū Ōkoku 琉球王国, 1429?-1879) but a great many works have been lost due to the hot and humid Okinawan climate, World War II, or other conditions and events, and there are extremely few extant. Even among those that survive, there are many that are in poor condition, and there are many conservation issues to address. In recent years, research has made many inroads that have resulted in clarification of the history of Ryukyuan painting. However, in terms of our understanding of painters associated with the Kaizuri Bugyōsho 貝摺奉行所 ${ }^{2}$ in Shuri 首里 and others com-

1 [Translator's note] The Yaeyama kuramoto was the government office overseeing the Miyako 宮古 and Yaeyama 八重山 Islands (i.e., Sakishima 先島) for the Ryukyuan royal court based at Shuri 首里 on the island of Okinawa

2 [Translator's note] The Kaizuri Bugyōsho (lit. "Office of the Magistrate of Mother-of-Pearl") was a government office that 
pared to the kuramoto painters (provincial painters of Sakishima), there is still much that remains unclear, and the same can be said of the wooden door paintings they produced.

For these reasons, we hope to clarify the condition of the wooden door paintings through a survey of the materials and techniques used in their production. This research report, touching upon the results of two surveys conducted on 24-26 January and 25-26 August, 2019, discusses comparisons with historical records and previous scholarship, and connects these with prospects for the future.

\section{The Kuramoto Painters and the Wooden Door Paintings of Miyara dunchi}

Miyara dunchi is a Ryukyu Kingdom-era private house in Ishigaki City 石垣市, Okinawa Prefecture. It is said to have been built in commemoration of the 1819 appointment of Tōen 當演 (d.u.), the eighth head of the Matsumō 松茂 family, to the position of administrator (kashira shoku 頭職) of Miyara magiri 宮良間切. ${ }^{3}$ It was named a nationally-designated Important Cultural Property (Building) in 1972.

Five wooden door paintings attributed to Yaeyama kuramoto painter Kyūna Anshin 喜友名安信 (1831-1892) and others ${ }^{4}$ survive within the house. The kuramoto painters were appointed as individuals of particular talent in painting techniques; when Western vessels came to the islands, they were responsible for producing sketches of the foreigners and their ships as reports to be sent to the royal court at Shuri, accompanying interpreters and aiding in communication through the use of images, and producing maps. The kuramoto government office conducted exams to select individuals for these official painter positions, and only the most talented were selected. Among those selected for appointment, individuals of even more exceptional talent were sent to Shuri to train and practice, or were granted special opportunities otherwise.

oversaw the production of lacquerware and certain other luxury items for the royal court's use.

3 [Translator's note] The Ryukyu Kingdom was divided into administrative districts known as magiri.

4 This information is based on interviews and other work by Kamakura Yoshitarō 鎌倉芳太郎 (1898-1983); "and others" refers to the presence of additional artists who were Anshin's followers. Kamakura, Okinawa bunka no ihō, vol. 2, Shashin-hen, p. 215. [n1]
From this we can understand that these official painter positions demanded high levels of skill and the fulfillment of important roles. As Kamakura Yoshitarō notes, the pigments believed to have been used at that time are still expensive and precious materials today. Kamakura writes that the last kuramoto painter, Miyara Ansen 宮良安宣 (1862-1931), told him that the pigments used were all imported from Fuzhou 福州 and stored by the kuramoto. ${ }^{5}$ By studying the wooden door paintings at Miyara dunchi, we can get a glimpse of the kuramoto painters' techniques. These paintings can also be expected to become a resource for future research on the relationship with the Shuri royal court and Kaizuri Bugyōsho, the system of master-apprentice relationships, etc., as well as on broader organizational or administrative structures of the time within which the painters were incorporated.

\section{The Current State of the Miyara dunchi Wooden Door Paintings}

Deterioration is considerable at Miyara dunchi, and a partial dismantling of the structure for repair purposes within the next few years is under consideration. Investigations into the materials and techniques used in these paintings are therefore being conducted so that in future the original wooden door paintings can be conserved, and reproductions installed for viewing in their place. To this end, in order to collaborate and exchange opinions with experts in various fields, Shimono Eikō 下野栄高 of the Yaeyama Board of Education Cultural Division, painting mounter Tōma Takumi 當間巧, Okinawa Prefectural Museum and Art Museum curator Shinohara Akane 篠原あかね, and Nizoe Marina 仁添まりな, PhD candidate at the Okinawa Prefectural University of the Arts, also accompanied us and contributed to conducting the survey.

5 Kamakura, Okinawa bunka no ihō, p. 214. [n2] [Translator's note] Due to both policy and maritime conditions, there was no official trade or direct official contact between Sakishima and mainland China during the early modern period. Pigments, along with any other Chinese-made products obtained by the officials of the Miyara dunchi, were most likely acquired via the royal court at Shuri, which held a monopoly within the Ryukyus on official trade with China. 


\section{- The Objects Surveyed}

The locations of the wooden door paintings surveyed are indicated in figure 1.

This survey examines five wooden door paintings in total, including four paintings of hawks with differing compositions, ${ }^{6}$ and one painting of Shōki 鍾埴 the Demon Queller.7 (The hawk paintings are differentiated by the use of the letters a-d.)

According to Miyara Yoshiaki 宮良芳明, proprietor of the Miyara dunchi house, the historical location of paintings three to five within the house is not known, so they have been hung together in one location as marked in figure 1. Details pertaining to the wooden door paintings noted in materials by Kamakura Yoshi$\operatorname{taro}^{-8}$ and from our survey are compiled in table 1.

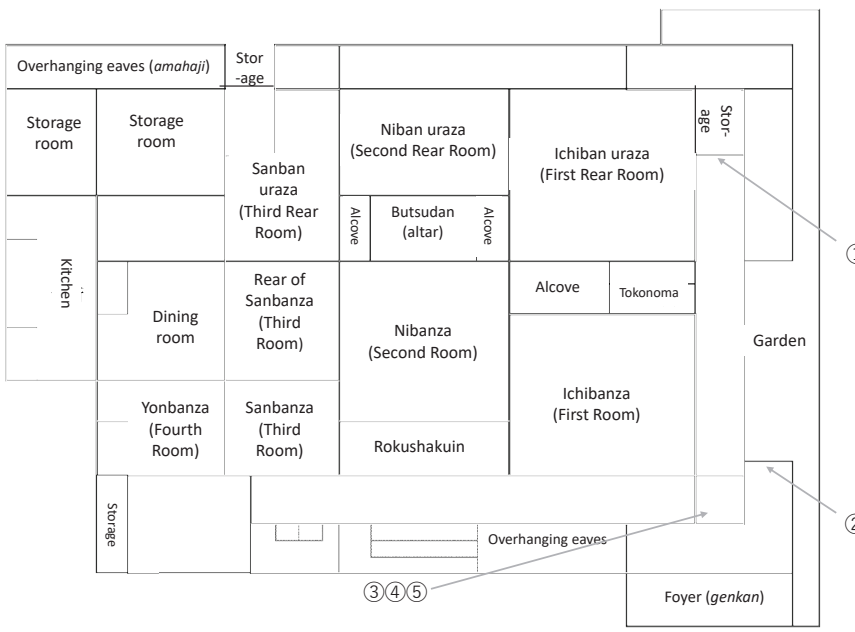

Figure 1. Miyara dunchi floor plan. Created by Taira Yūki, based on materials distributed at Miyara dunchi, entitled "Kyū Miyara dunchi." Permission of Ishigaki City Board of Education.
(1) Painting of a hawk a

Painted onto a section of the wall

(2) Painting of a hawk b

Painted onto a section of the wall

(3) Painting of a hawk c

Painting of a hawk $\mathrm{d}$ is on the reverse side

(4) Painting of a hawk $\mathrm{d}$

Painting of a hawk $\mathrm{c}$ is on the reverse side

(5) Painting of Shōki

Swinging door. No painting on the reverse side.

Table 1. Listing of wooden door paintings. Based on Kamakura, Okinawa bunka no ihō, vol. 2, Shashin-hen, pp. 299-301, and a visual survey.

\begin{tabular}{|c|c|c|c|c|c|c|c|}
\hline No. & Title (according to Kamakura) & $\begin{array}{l}\text { Title (as represented in } \\
\text { our own notes) }\end{array}$ & $\begin{array}{l}\text { Letters } \\
\text { assigned }\end{array}$ & $\begin{array}{c}\text { Painter } \\
\text { (according to } \\
\text { Kamakura) }\end{array}$ & $\begin{array}{c}\text { Color } \\
\text { (current } \\
\text { condition) }\end{array}$ & $\begin{array}{l}\text { Height } \\
(\mathrm{mm})\end{array}$ & $\begin{array}{l}\text { Width } \\
\text { (mm) }\end{array}$ \\
\hline 1 & $\begin{array}{l}\text { Yaeyama Miyara dunchi sugiita-e } \\
\text { taka-zu (Yaeyama Miyara dunchi } \\
\text { cedar panel painting, hawk) }\end{array}$ & $\begin{array}{l}\text { Taka-zu (Painting of a } \\
\text { hawk, figure 2) }\end{array}$ & a & $\begin{array}{l}\text { Kyūna Anshin } \\
\text { and others }\end{array}$ & Yes & 1900 & 955 \\
\hline 2 & $\begin{array}{l}\text { Yaeyama Miyara dunchi sugiita-e } \\
\text { taka-zu (Yaeyama Miyara dunchi } \\
\text { cedar panel painting, hawk) }\end{array}$ & $\begin{array}{l}\text { Taka-zu (Painting of a } \\
\text { hawk, figure } 3 \text { ) }\end{array}$ & $\mathrm{b}$ & $\begin{array}{l}\text { Kyūna Anshin } \\
\text { and others }\end{array}$ & Yes & 1880 & 960 \\
\hline 3 & $\begin{array}{l}\text { Yaeyama Miyara dunchi sugiita-e } \\
\text { taka-zu (Yaeyama Miyara dunchi } \\
\text { cedar panel painting, hawk) }\end{array}$ & $\begin{array}{l}\text { Taka-zu (Painting of a } \\
\text { hawk, figure } 4 \text { ) }\end{array}$ & c & $\begin{array}{l}\text { Kyūna Anshin } \\
\text { and others }\end{array}$ & Yes & 1885 & 915 \\
\hline 4 & (not mentioned) & $\begin{array}{l}\text { Taka-zu (Painting of a } \\
\text { hawk, figure 5) }\end{array}$ & $\mathrm{d}$ & (not mentioned) & No & 1885 & 915 \\
\hline 5 & (not mentioned) & $\begin{array}{l}\text { Shōki-zu (Painting of } \\
\text { Shōki, figure 6) }\end{array}$ & & (not mentioned) & Yes & 1790 & 825 \\
\hline
\end{tabular}

6 We use the title "Painting of a hawk" as in Kamakura, Okinawa bunka no ihō, but not as a formal title for the work. Note, however, that since Kamakura also indicates that "these hawk paintings at Miyara dunchi may be of eagles" (Kamakura, Okinawa bunka no ihō, p. 215), future consideration may be necessary. [n3]

7 There are various theories, such as this painting being described as an "Image of Guan Yu"; see Okinawa-ken Kyōikuchō Bunkaka, Kennai kaiga, p. 73. Given the many similarities in the clothing, sword, appearance of the figure, and other elements present in Shōka Shōki-zu (Painting of Shōki Beneath a Pine) by Ōhama

Zenkei and Kishi Shōki-zu (Painting of Shōki Riding a Lion) at Nakagusuku udun, however, the authors designate Shōki (Painting of Shōki) as the subject rather than Guan Yu. [n4] For illustrations see Kamakura, Okinawa bunka no ihō, vol. 2, Shashinhen, figs. pp. 298 (Zenkei) and 182 (Nakagusuku udun).

8 Kamakura, Okinawa bunka no ihō, vol. 2, Shashin-hen, pp. 299-301. [n5] 


\section{- Survey Methods}

The following five methods were used in the survey:

1. Comparison with Kamakura Yoshitarō's materials: A comparison of photographs of three of the Miyara dunchi wooden door paintings in Kamakura, Okinawa bunka no ihō, vol. 2, Shashin-hen, with their current condition.

2. Visual examination: To the extent possible by eye, visual examination of the condition (cracks, peeling paint, etc.), linework, and subject matter of the wooden door paintings.

3. Ultraviolet light: UV light was shone on portions painted white to investigate whether they were painted with gofun 胡粉 (a white pigment made from seashells) or with lead white. Where lead white is present, it shows as white under UV light. However, since this is a simple method, chemical analysis will later be performed to identify the pigments. Due to the deterioration of the works, UV light was not used for a lengthy period.

4. Infrared camera: Photographs reveal sumi ink lines covered by pigment.

5. Microscopes: Magnifying areas where pigment was used, the presence or absence of mineral pigment particles can be determined. We investigated whether mineral pigments or dyes were used.

\section{- Current State of the Wooden Door Paintings}

Below, we divide our findings into four sections:

1. Comparison with materials by Kamakura Yoshitarō: Hawk paintings a, b, and c (figures 7, 9, 11), which can be seen in glass plate photographs by Kamakura Yoshitarō, are compared with the current state of the paintings (figures $8,10,12$ ).

From comparison with the Kamakura Yoshitarō materials, it can be clearly seen that the paint is continuing to peel. Looking at the door paintings seen in figures 9 and 11 and comparing them with the current state of the doors, the branches seen in the upper section (figure 10) and the section believed to depict rocks and plants in figure 11 (see figure 12) have almost completely disappeared.
2. Condition of the Doors: We investigated the condition of the wooden doors chiefly through visual examination. There is ongoing deterioration due to the rusting and expansion of the iron nails seen in the upper portion of the images, which causes the wooden boards to split. The doorframe is now broken and does not retain its original shape (see figure 13). Further, termite damage was visible on the frame of the door featuring hawk paintings $\mathrm{b}$ and $\mathrm{c}$ (figure 14). Other damage on doorframes (figure 15) and gaps between the door and the doorframe caused by deformation (figure 16) were also observed in many places.

3. Underdrawings: We investigated the ink line brushwork and pigments used on the doors through visual examination and infrared photography. The infrared photography was performed using an infrared camera: SONY F-828; lens filter: KenKo R72.

Focusing on the linework in hawk paintings $a, b$, and c (figures 2, 3, 4), and looking at the hawks, stones, and plants, many similarities can be seen in the brushwork, pigments, and use of color. They are thought to have been produced by the same artists. The linework in hawk painting d (figure 5), however, clearly differs from the other four works. For example, focusing on the way the hawk is depicted, in hawk paintings a, b, and $c$, the linework gives a sense of the patterns on the hawks' wings. By contrast, in hawk painting $d$, the linework clearly differs. The modulation or force of the lines, the strength of the placing and lifting of the brush, and other factors reflect brushwork that gives a sense of modeled portions of the hawk; we believe this to be the work of a particularly skilled painter. Even if we compare the faces of the hawks in hawk paintings $b$ (figure 17) and d (figure 18), the difference is clear. The same difference was noted in the linework of the rocks.

The differences are clear in comparing hawk a (figure 19) and hawk d (figure 20) as well. In contrast to the touches expressing a sense of a rugged feeling in the rocks in hawk a (figure 19), in hawk d (figure 20), the brushwork conveys a sense of the modeling of the front and back of the rocks, and of their strength. Considering these two points as well, it is believed that the painters clearly differed.

4. The Media Utilized: We investigated the pigments utilized in the wooden door paintings by using UV light and by an examination using an electron microscope (Dino-Lite Pro2, model number: DINOAD413TAI2 $\mathrm{V})$. 
Table 2. Pigments utilized (from investigations by visual examination, UV light, and electron microscope).

\begin{tabular}{|c|l|l|c|l|}
\hline No. & \multicolumn{1}{|c|}{ Title (according to Kamakura) } & $\begin{array}{c}\text { Title (as represented in our } \\
\text { own notes) }\end{array}$ & $\begin{array}{c}\text { Letters } \\
\text { assigned }\end{array}$ & \multicolumn{1}{|c|}{ Pigments Utilized } \\
\hline 1 & $\begin{array}{l}\text { Yaeyama Miyara dunchi sugiita-e } \\
\text { taka-zu (Yaeyama Miyara dunchi } \\
\text { cedar panel painting, hawk) }\end{array}$ & $\begin{array}{l}\text { Taka-zu (Painting of a hawk, } \\
\text { figure 2) }\end{array}$ & a & $\begin{array}{l}\text { sumi ink, gofun, brown dye, lead } \\
\text { white?, vermillion? }\end{array}$ \\
\hline 2 & $\begin{array}{l}\text { Yaeyama Miyara dunchi sugiita-e } \\
\text { taka-zu (Yaeyama Miyara dunchi } \\
\text { cedar panel painting, hawk) }\end{array}$ & $\begin{array}{l}\text { Taka-zu (Painting of a hawk, } \\
\text { figure 3) }\end{array}$ & b & $\begin{array}{l}\text { sumi ink, gofun, lead white?, } \\
\text { vermillion? }\end{array}$ \\
\hline 3 & $\begin{array}{l}\text { Yaeyama Miyara dunchi sugiita-e } \\
\text { taka-zu (Yaeyama Miyara dunchi } \\
\text { cedar panel painting, hawk) } \\
\text { (no record) }\end{array}$ & $\begin{array}{l}\text { Taka-zu (Painting of a hawk, } \\
\text { figure 4) }\end{array}$ & $\mathrm{c}$ & $\begin{array}{l}\text { sumi ink, gofun, verdigris, lead white?, } \\
\text { vermillion? }\end{array}$ \\
\hline 5 & $\begin{array}{l}\text { (no record) } \\
\text { faka-zu (Painting of a hawk, } \\
\text { figure 5) }\end{array}$ & $\begin{array}{l}\text { Shōki-zu (Painting of Shōki, } \\
\text { figure 6) }\end{array}$ & sumi ink \\
\hline
\end{tabular}

Through visual examination, sumi ink, copper green (verdigris), two types of white pigment, brown pigment, and blue pigment could be discerned. It is highly likely that the white pigments are lead white or gofun. Ultraviolet light was used to determine this; areas which shone white under the UV light are very likely lead white. The breasts of the hawks in hawk paintings a, b, and c, the sword of Shōki, and the whites of his eyes reflected the UV light in this way (figures 21, 23, 24).

Further, in areas where the pigments used could not be determined by eye, an electron microscope was used to determine the presence or absence of mineral pigment particles (figure 22). Areas where the presence of pigment particles could be confirmed included the leaves on the pine tree in hawk painting $c$, and in Shōki's belt (figures 25, 26), cap, and sword hilt. From these results, the pigment on the belt is believed to be ultramarine and, on the cap, verdigris. ${ }^{9}$ Mineral pigment particles could not be confirmed for the brown pigment used in the autumn leaves in hawk painting a, for the skin in the painting of Shōki, or for the bluegreen pigment used in Shōki's garments; therefore, it is thought that these were painted with dyes. Similarly, a white pigment used in the tassel on Shōki's sword

9 [Translator's note] The original Japanese report at this point refers to "figures 27 and 28," but as these images were not available at the time of publication, they were omitted. As the images remain unavailable at this time, the words "figures 27 and 28 " are omitted from this English version and the images originally labeled as figures $29-32$ are now renumbered as figures 27-30. and believed to be $g$ ofun was painted as an undercoat, ${ }^{10}$ with a red pigment lacking in mineral pigment particles applied over it. Comparing this against the pigments mentioned when Kamakura interviewed Miyara Ansen, it is believed this is probably vermillion, ${ }^{11}$ but in order to reach a better conclusion as to the pigment it is necessary to conduct further investigation, including chemical analysis. The pigments that we were able to distinguish in the current survey are listed in table 2.

\section{Survey Results}

Three points were made clear as a result of this survey. First, the pigments used on the wooden door paintings include the natural mineral pigments ultramarine and verdigris. It will be necessary to perform chemical analysis to identify other pigments, but even at the current stage, we can see that these were lavishly produced wooden door paintings.

Second, the painters of the wooden door paintings

10 When Kamakura performed a survey in Yaeyama, he collected his notes on the pigments used at the Gongendō 権現堂 in his notebooks. Since those notes include descriptions of layers of pigment painted over a gofun ground, it is possible to point to the same technique being used here. Hateruma and Asō, Kamakura Yoshitarō shiryōshū, p. 79. [n6]

[Translator's note] The Yaeyama Gongendō八重山権現堂 is an eighteenth-century shrine located near Miyara dunchi; it is the only example of Ryukyuan shrine architecture surviving from the time of the Ryukyu Kingdom. Suzuki, Miyamoto, and Ushikawa, "Ryūkyūan Architecture," p. 87.

11 Kamakura, Okinawa bunka no ihō, p. 214. [n7] 
differed. Initially it was thought that all the wooden door paintings were handled by the same painter. Based on this study, however, we are able to state that the creator of hawk paintings a-c differs from the creator of hawk painting d. As discussed above, we believe hawk painting $\mathrm{d}$ to have been produced by a skilled painter. One interpretation is that this was Kyūna Anshin and that hawk paintings a-c were painted by his followers. The brush techniques on the leaves in hawk painting a (figure 27) and the use of light ink in the stems resembles Anshin's style (figure 28), however. Additionally, in the representation of rocks, the brushwork in hawk painting d (figure 20) and in Anshin's rocks (figure 28) clearly differ. Based on these points, the painter of hawk paintings $a-c$ is thought to be Anshin, as indicated in Kamakura's materials as well. Further, compared to the wooden doors the other works are painted on, the damage to hawk painting $\mathrm{d}$ is considerable, and it appears to be painted only in ink lines, with no pigments able to be confirmed. The influence of Chinese painting styles can be strongly seen in the awareness of line, judging from the modulation of the brushstrokes as the brush was placed onto the wood and lifted up. Not only this, but regarding brush techniques from Chinese painting, this can be surmised to be by a painter with some degree of accumulated training in Chinese painting styles. As a result, these works might also be thought to be by Anshin's teacher Mō Buntatsu 毛文達 (Kohagura Anshō 古波蔵安章, 1838-1886), Buntatsu’s teacher Mō Chōki 毛長禧 (Sadoyama Anken 佐渡山安健, 1806-1865), or Ōhama Niya 大浜仁屋 (Zenkei 善繁, 1761-1814), who participated in the production of the door paintings for the inner chambers of the Yaeyama Gongendo 八重山権現堂. Works depicting the motifs in these paintings in a similar fashion include Mō Chōki’s Botan onagadori-zu 牡丹尾長鳥図 (Painting of Peonies and Long-Tailed Chickens) and Taka suzume kareki fuyō-zu 鷹雀枯木芙蓉図 (Painting of a Hawk and Sparrows on an Old Hibiscus Tree). Figure 29 is a left-right inverted image of a detail from Painting of Peonies and LongTailed Chickens. Although the rocks depicted here do not extend towards the background as in the Miyara dunchi door painting (figure 20), there are many similarities, such as in the strength of the brushstrokes, the inclusion of moss, and the form of the rocks. Figure 30 similarly shows a left-right inverted detail of Painting of a Hawk and Sparrows on an Old Hibiscus Tree. Comparing it with figure 18 , from the depiction of the outer corner of the eye and the beak, the two both feature brushwork which gives a sense of the construction of the hawk's face.

The painting of Shōki is also believed to have been by Anshin. However, given its superior conservation condition compared to the other four works, the use of richer pigments, and the absence of photographic records of this work in Kamakura's materials, it may have been painted later than the other four. This has yet to be confirmed, however. It is necessary to take these considerations into account based on surviving works, including the possibility that these were painted by the abovementioned painters, but it is clear that an artist with a degree of training in Chinese painting or a painter possessing techniques learned via the court painters of the Kaizuri Bugyōsho of the Shuri royal court contributed to the production of the wooden door paintings at Miyara dunchi. Finally, it became clear through this survey that the wooden door paintings are critically damaged due to the expansion of the rusting iron nails in the doors that has caused some of the doors to split.

As a result, the paintings are in an unfortunate state, with some of the wooden doorframes broken, and some of the paintings misaligned with the doorframes. At the time of our first visit, efforts were made to conserve the state of the doors, but on our second visit, deterioration had continued further. According to master painting mounter Tōma Takumi, who accompanied us on our second visit, if the iron nails are not removed and the expansion stopped, the deterioration will only continue. Taking advantage of the opportunity provided by this survey, and based on the advice of Mr. Tōma, a set of shelves were constructed to allow three works - that had, until now, been installed upright - to be instead stored flat in a room within Miyara dunchi as a simple conservation measure.

From the results of this survey, and considering what can be seen of the master-student system or relationships with the Shuri royal court and Kaizuri Bugyōsho, the pigments and wooden ground used, and through further analysis of the techniques employed, we can see that the Miyara dunchi wooden door paintings have the potential to be important pieces that play a role in our understanding of Ryukyuan painting. The creation of reproductions hereafter is under consideration as a means to conserve the extant door paintings. Further, we hope that it will be possible to discern the processes the painters of that time deployed in producing these works. For example, it is difficult through simple vi- 
sual examination to determine the use of gojiru 吳汁 (a liquid made from seaweed and soybean powder), nikawa 膠 (animal hide glue), or other materials; the painters' handling of the thickness of the pigments; their handling of the brush while thinking about loading it with ink; their approach to the wooden panels; and other considerations, but we think it may be possible to analyze these aspects in the process of copying the techniques.

\section{Conclusion}

The goal of this investigation was to research the materials and techniques used in the Miyara dunchi wooden door paintings, and to evaluate their current conservation status. This survey employed comparison with photographs, notebooks, and other records by Kamakura Yoshitarō; visual examination of the state of the works; and the use of an electron microscope and other equipment to investigate the materials and techniques employed. When comparing these works with those by painters associated with the Kaizuri Bugyōsho centered at Shuri, and by others, many points pertaining to the kuramoto painters remain obscure. Even considering this, the survey of the Miyara dunchi wooden door paintings cast into relief the possible existence of new painters, the use of lavish pigments, and matters pertaining to conservation.

Future goals include determining the identity of the painters and considering partially disassembling the paintings for repair and conservation by producing and replacing them with reproductions. In the current survey, we were able to engage in an exchange of opinions with Mr. Miyara and with experts in various fields.

Hereafter, through the copying and conservation of the paintings and deeper research into the artists and techniques, we can expect new developments in research into the lost wooden panel paintings from Engakuji and Nakagusuku $u d u n$ based on the examples of the Miyara dunchi paintings.

\section{Reference List}

Harada Ayumi 原田あゆみ. “Kamakura Yoshitarō no zenki Ryūkyū geijutsu chōsa to bijutsukan no henkan” 鎌倉
芳太郎の前期琉球芸術調查と美術観の変遷. Okinawa geijutsu no kagaku 沖縄芸術の科学 11 (1999), pp. 25-137. Hateruma Eikichi 波照間永吉 and Asō Shin'ichi 麻生伸一, eds. Kamakura Yoshitarō shiryōshū (nōto hen) 鎌倉芳太郎 資料集 (ノート編), vol. 4. Okinawa Kenritsu Geijutsu Daigaku Fuzoku Kenkyūjo, 2016.

Ishigaki-shi Kyōiku Iinkai 石垣市教育委員会, ed. Ishigakishi no bunkazai 石垣市の文化財. Ishigaki-shi Kyōiku Iinkai, 2014.

Ishigaki-shi Yaeyama Hakubutsukan 石坦市八重山博物館, ed. Tokubetsu kikaku Kubashima Seiki ten 特別企画久場島 清輝展. Ishigaki-shi Yaeyama Hakubutsukan, 1990.

Ishigaki-shi Yaeyama Hakubutsukan, ed. Yaeyama kuramoto eshi gakōshū八重山蔵元絵師画稿集. Ishigaki-shi Yaeyama Hakubutsukan, 1993.

Jahana Sawako 謝花佐和子 and Nakazato Nagisa 仲里 なぎさ, eds. Uruwashiki Ryūkyū no kiroku: Kamakura Yoshitarō ga hakken shita bi 麗しき琉球の記録: 鎌倉芳太郎 が発見した美. Naha: Okinawa Bunka no Mori, 2014.

Kamakura Yoshitarōo 鎌倉芳太郎. Okinawa bunka no ihō 沖縄文化の遺宝. Two vols. (vol. 1, title as here; vol. 2, Okinawa bunka no ihō, Shashin-hen 写真編). Iwanami Shoten, 1982.

Kamakura Yoshitarō. "Sakishima geijutsu to Tōrinji no inshō” 先嶋㙯術と桃林寺の印象. Yaeyama bunka 八重 山文化 2 (1974), pp. 4-35.

Kugai Noriko 久貝典子. “Kamakura nōto kara mita 'Ryūkyū geijutsu chōsa’”鎌倉ノートからみた「琉球芸術 調查」. Okinawa geijutsu no kagaku 27 (2015), pp. 63-95.

Kugai Noriko. "Kamakura Yoshitarō no Ryūkyū geijutsu chōsa (jō)” 鎌倉芳太郎の琉球芸術調查 (上). Okinawa bunka 沖縄文化 96 (2003), pp. 1-39.

Kugai Noriko. "Kamakura Yoshitarō no Ryūkyū geijutsu chōsa (ge)” 鎌倉芳太郎の琉球芸術調査 (下). Okinawa bunka 97 (2004), pp. 87-112.

Kyan Chie 喜屋武千恵 and Taira Yūki 平良優季. “Kyū Miyara dunchi itadoe no genjō to tenbō” 旧宮良殿内板 戸絵の現状と展望. Okinawa Kenritsu Geijutsu Daigaku $k i y \bar{o}$ 沖縄県立芸術大学紀要 28 (2020), pp. 29-42.

Miyagi Tokumasa 宮城篤正. "Kennai kaiga ihin chōsa hōkoku” 県内絵画遺品調査報告. Okinawa Kenritsu Hakubutsukan kiyō 沖縄県立博物館紀要 5 (1979), pp. 17-38.

Okinawa-ken Kyōikuchō Bunkaka 沖縄県教育庁文化課, ed. Okinawa-ken bunkazai chōsa hōkokusho 沖縄県文 化財調查報告書, vol. 11, Shōwa 52 nendo jūyō rekishi shiryō chōsa kennai kaiga ihin chōsa hōkokusho 昭和五十 二年度重要歴史資料調查県内絵画遺品調查報告書. Okinawa-ken Kyōiku Iinkai, 1978. 
Suzuki Kakichi 鈴木嘉吉, Miyamoto Chōjirō 宮本長二郎, and Ushikawa Yoshiyuki 牛川喜幸. “Ryūkyūan

Architecture: Its History and Features.” In Okinawa bijutsu zenshū 沖縄美術全集, vol. 5, ed. Okinawa Bijutsu Zenshū Kankō Iinkai 沖縄美術全集刊行委員会,

pp. 87-104. Naha: Okinawa Taimusu-sha, 1989.

Tōkyō Geijutsu Daigaku Daigakuin Bunkazai Hozongaku Nihonga Kenkyūshitsu 東京藝術大学大学院文化財 保存学日本画研究室, ed. Zukai Nihonga no dentō to keishō: Sozai, mosha, shūfuku 眓解日本画の伝統と継承: 素材·模写·修復. Tōkyō Bijutsu, 2002.

Yonahara Kei 与那原恵. Shurijō e no sakamichi: Kamakura Yoshitarō to kindai Okinawa no gunzō 首里城への坂道: 鎌倉芳太郎と近代沖縄の群像. Chikuma Shobō, 2013. 


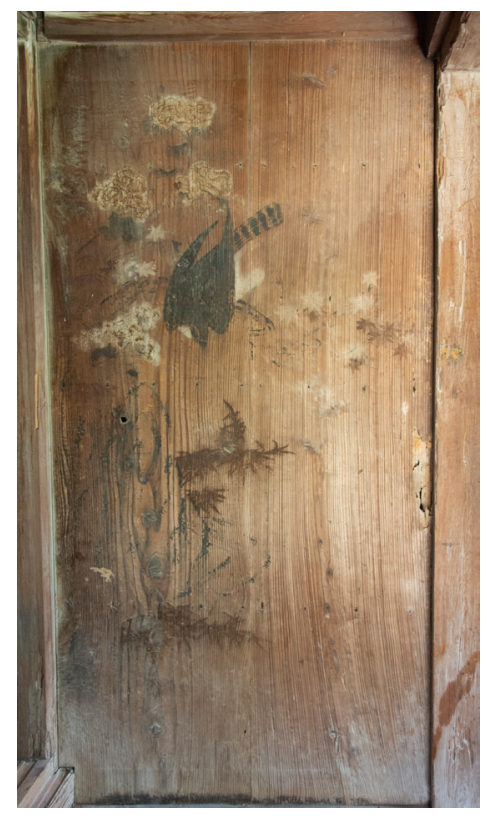

Figure 2. (1) Painting of a hawk, a, current condition. Painted onto a section of the wall. Color is present. Photograph by Nizoe Marina. Permission of Ishigaki City Board of Education.

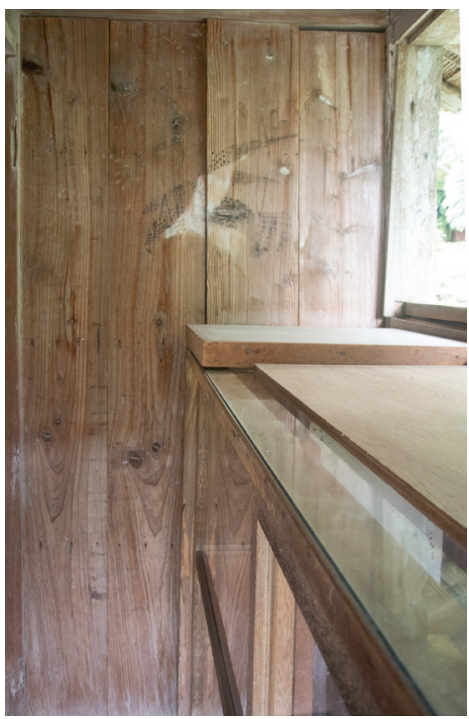

Figure 3. (2) Painting of a hawk, b, current condition. Painted onto a section of the wall. Color is present. There is an exhibition case in front of the door; since this could not be moved, photography of the lower right portion of the door was not possible. Photograph by Nizoe Marina. Permission of Ishigaki City Board of Education.

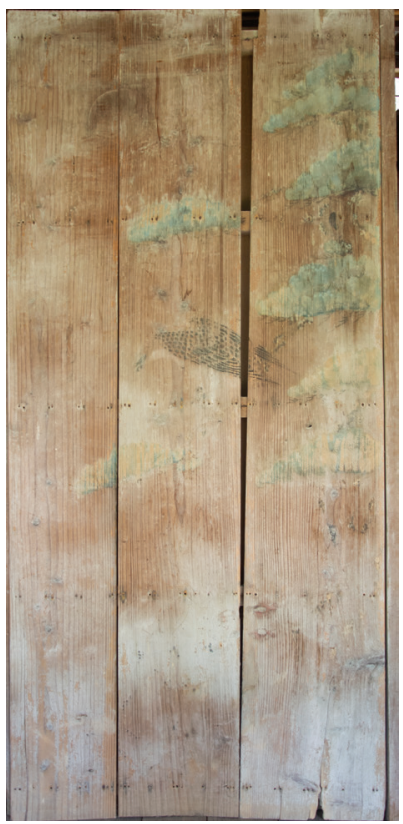

Figure 4. (3) Painting of a hawk, $c$, current condition. Hawk d is painted on the reverse side. Color is present. Photograph by Nizoe Marina. Permission of Ishigaki City Board of Education.

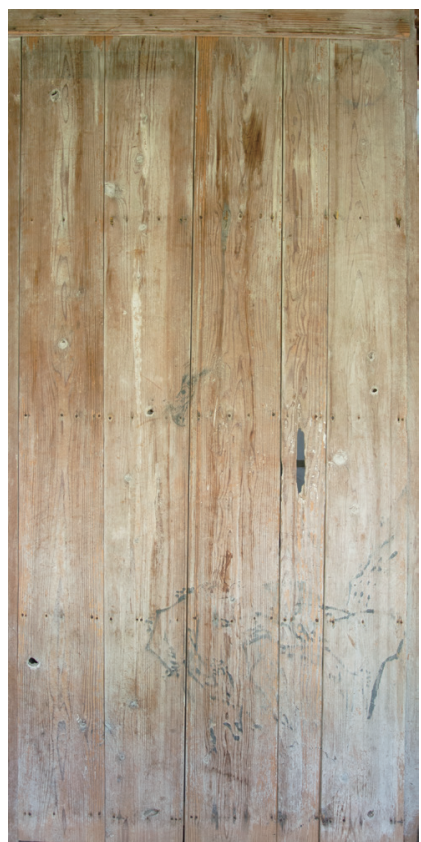

Figure 5. (4) Painting of a hawk, $d$, current condition. Hawk c is painted on the reverse side. No color is present. Photograph by Nizoe Marina. Permission of Ishigaki City Board of Education.

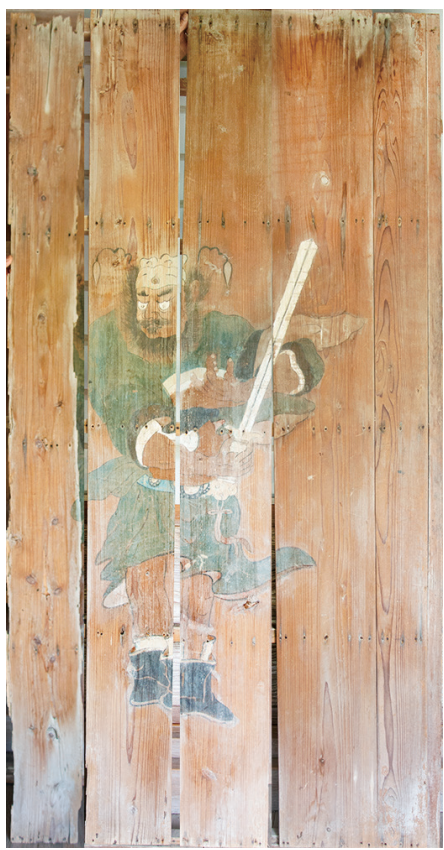

Figure 6. (5) Painting of Shōki, current condition Hinges are attached above and below to the left of the image, making for a swinging door. Color is present. Photograph by Nizoe Marina. Permission of Ishigaki City Board of Education. 


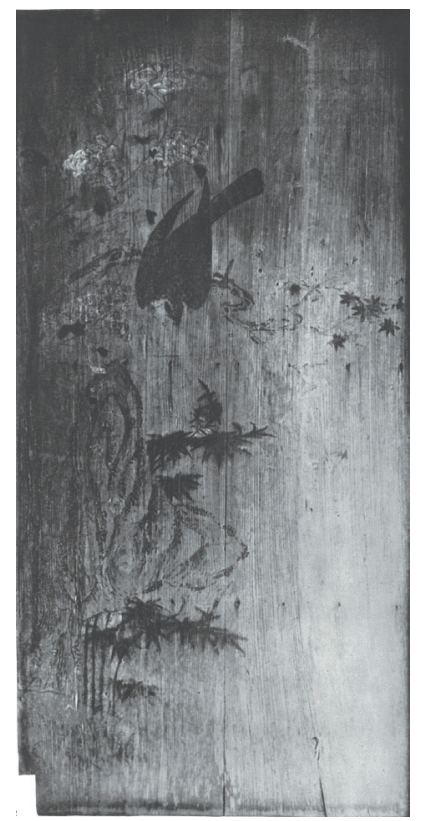

Figure 7. Painting of a hawk. Photograph by Kamakura Yoshitarō. Collection of Okinawa Prefectural University of the Arts Library, with permission.

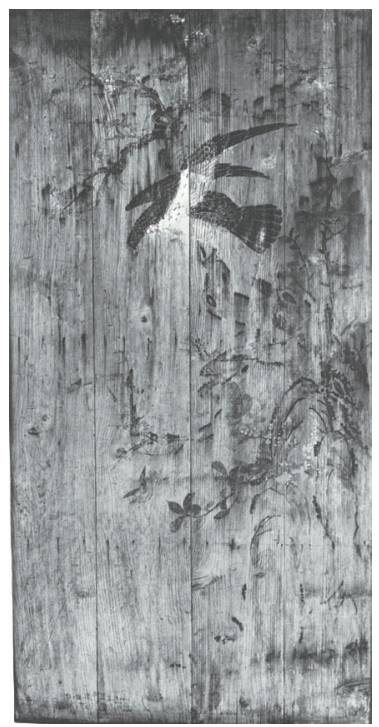

Figure 9. Painting of a hawk. Photograph by Kamakura Yoshitarō. Collection of Okinawa Prefectural University of the Arts Library, with permission.

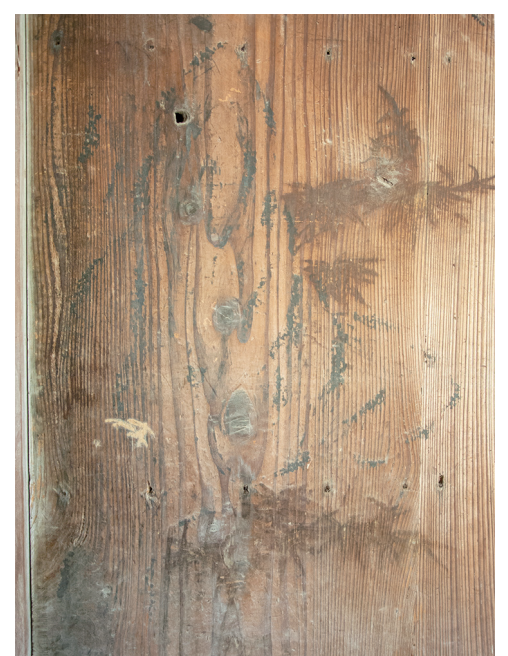

Figure 8. Painting of a hawk, a (detail), current condition. The lower portion of the composition. Photograph collection of Chie Kyan. Permission of Ishigaki City Board of Education.

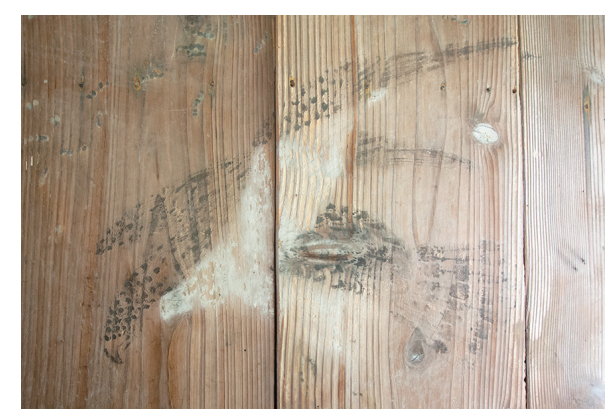

Figure 10. Painting of a hawk, b (detail), current condition. The upper portion of the composition. Photograph collection of Chie Kyan. Permission of Ishigaki City Board of Education. 


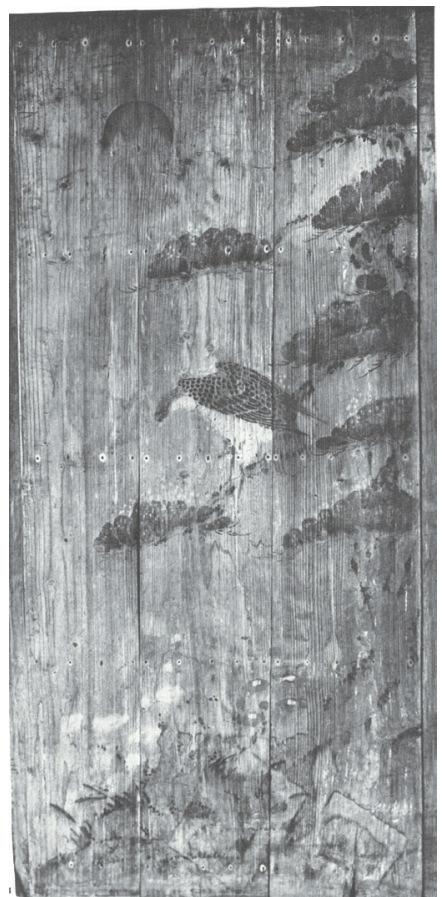

Figure 11. Painting of a hawk. Photograph by Kamakura Yoshitarō. Collection of Okinawa Prefectural University of the Arts Library, with permission.

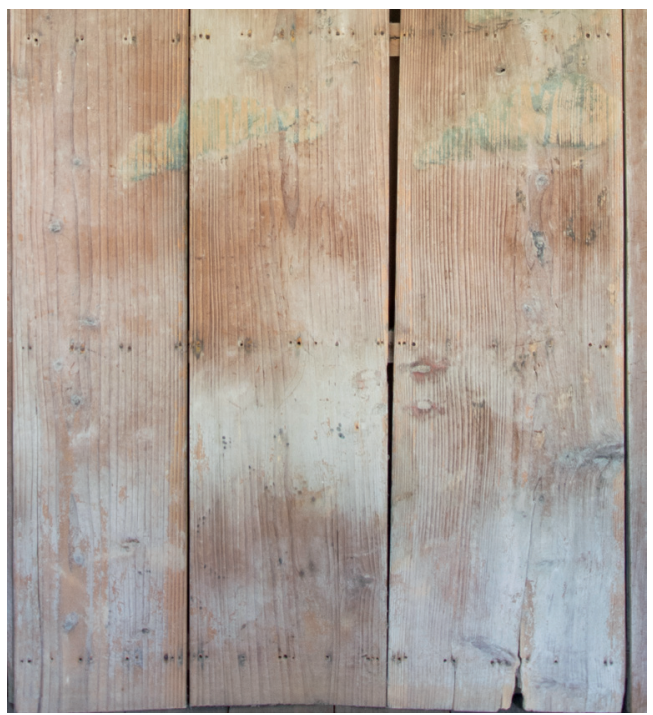

Figure 12. Painting of a hawk, c (detail), current condition. Lower portion of the composition. Photograph collection of Chie Kyan. Permission of Ishigaki City Board of Education.
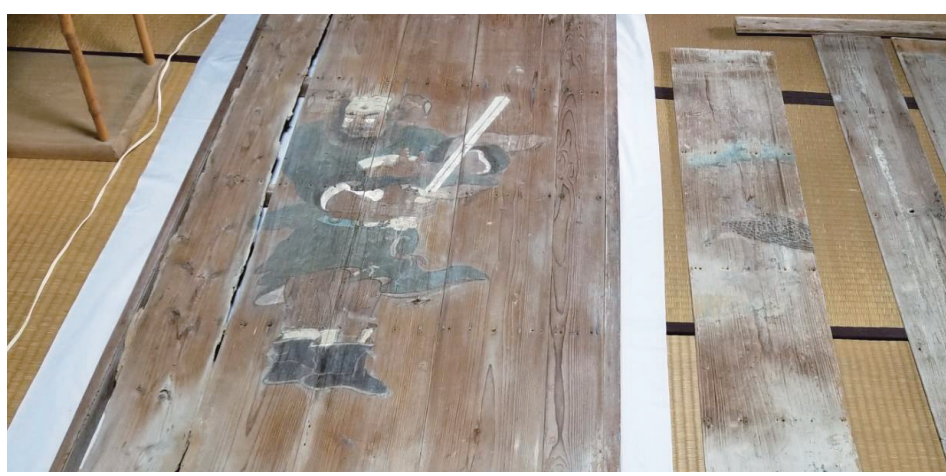

Figure 13. Current condition. From left: paintings of Shōki and hawks $b$ and $c$, removed from their doorframes and laid on the floor. Photograph collection of Chie Kyan. Permission of Ishigaki City Board of Education.

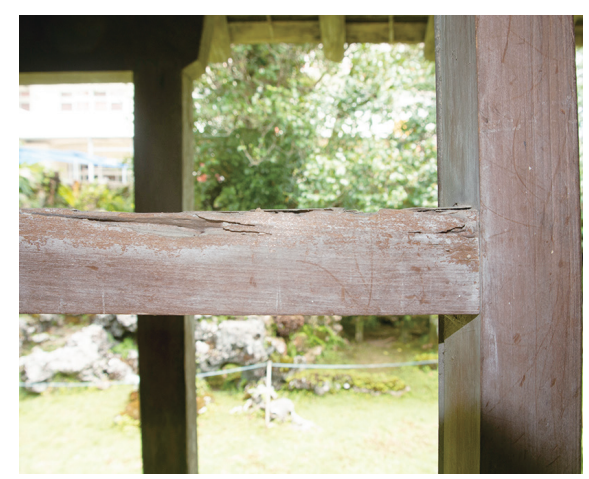

Figure 14. Current condition. The doorframe for hawk paintings $b$ and $c$. Termite damage remains in places. Photograph collection of Chie Kyan. Permission of Ishigaki City Board of Education. 


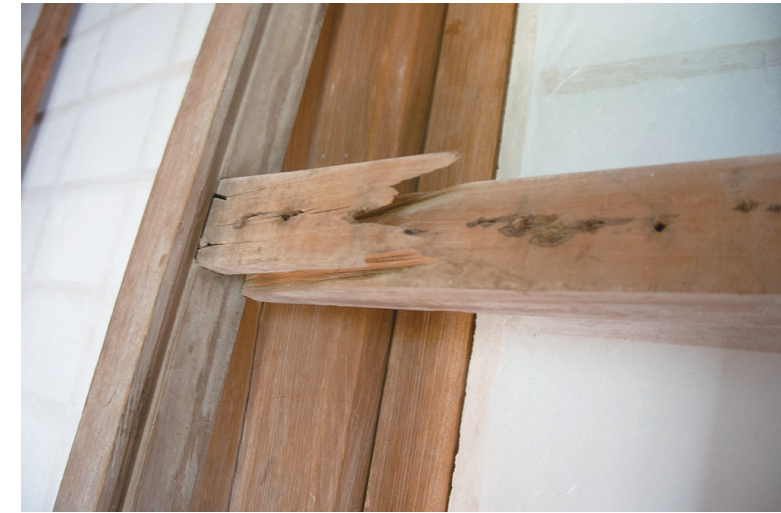

Figure 15. Current condition. The doorframe for hawk paintings $b$ and $\mathrm{c}$. The iron nails have expanded due to rusting, and the wooden frame has been damaged. Photograph collection of Chie Kyan. Permission of Ishigaki City Board of Education.

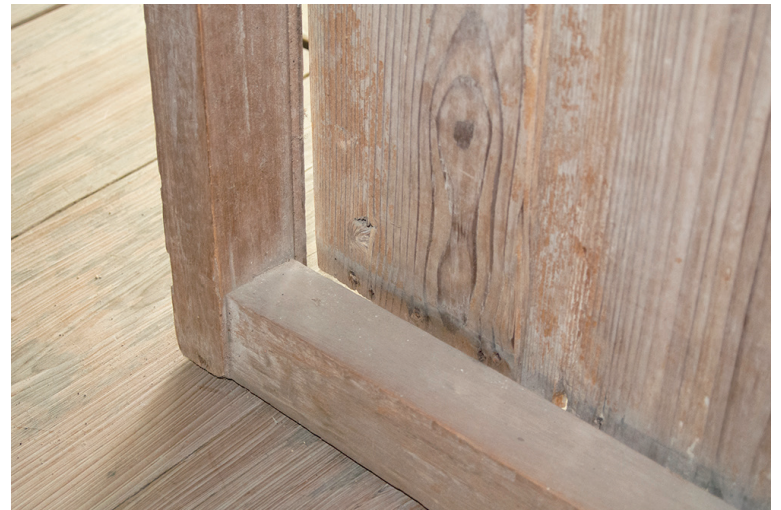

Figure 16. Current condition. Reverse side of painting of Shōki. The wooden planks of the door and the doorframe have become misaligned. Photograph collection of Chie Kyan. Permission of Ishigaki City Board of Education.

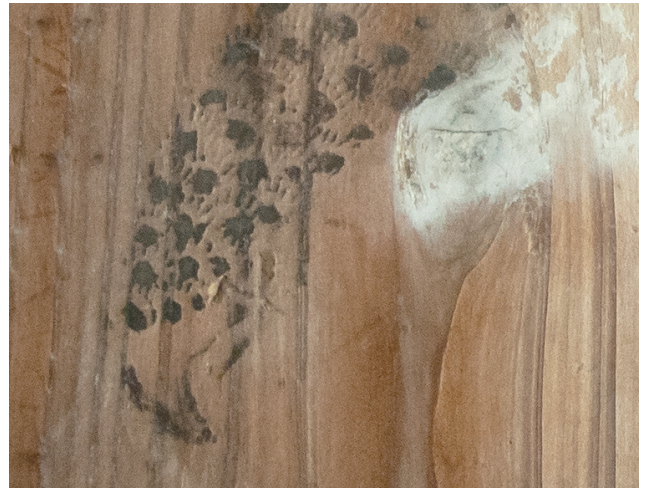

Figure 17. Painting of a hawk, b (detail). Photograph collection of Chie Kyan. Permission of Ishigaki City Board of Education.

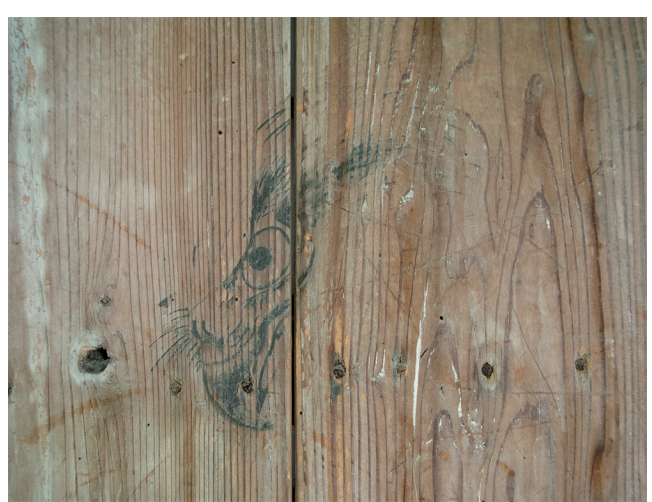

Figure 18. Painting of a hawk, $d$ (detail, infrared photography). Photograph by Tōma Takumi. Permission of Ishigaki City Board of Education. 


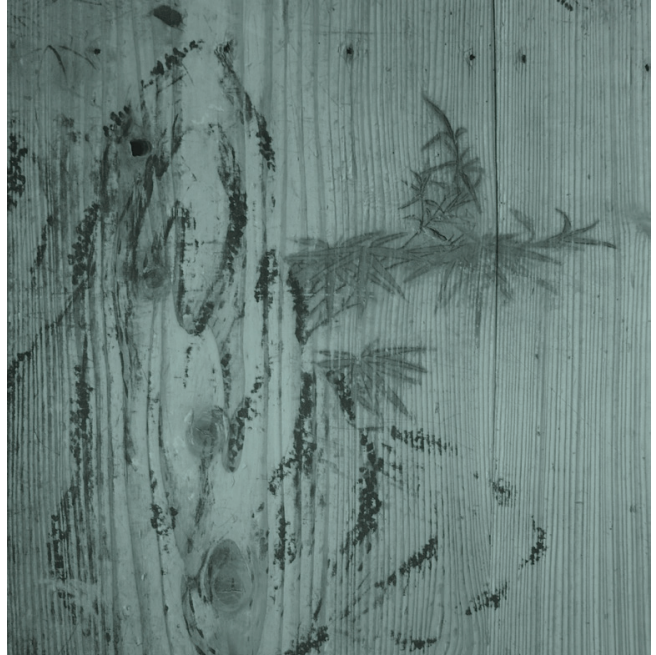

Figure 19. Painting of a hawk, a (detail, infrared

photography). Photograph by Tōma Takumi. Permission of Ishigaki City Board of Education.

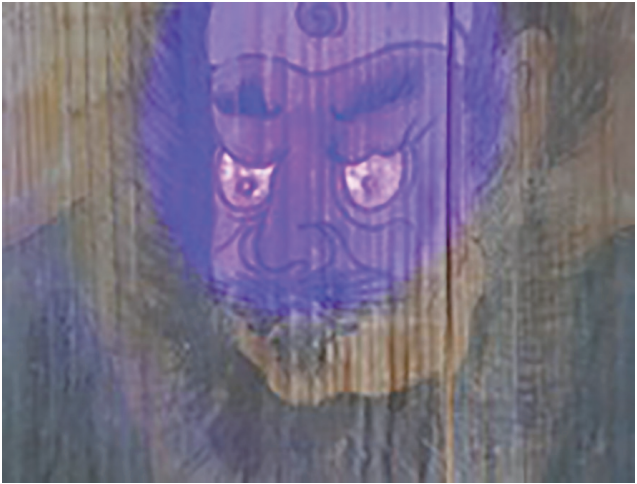

Figure 21. Painting of Shōki (detail). Under UV light, the whites of the eyes shine white. Photograph by Nizoe Marina. Permission of Ishigaki City Board of Education.

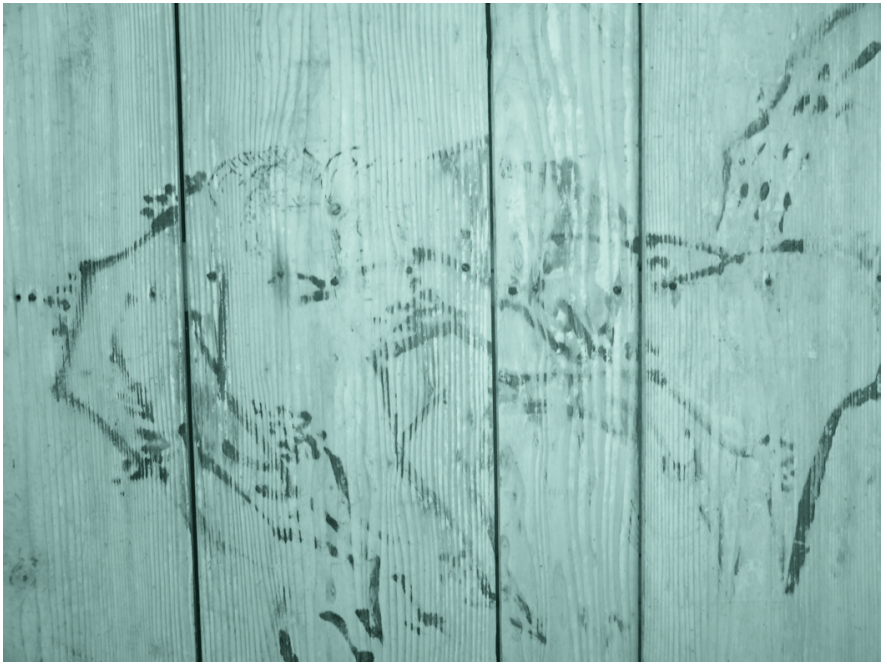

Figure 20. Painting of a hawk, $d$ (detail, infrared photography). Photograph by Tōma Takumi. Permission of Ishigaki City Board of Education.

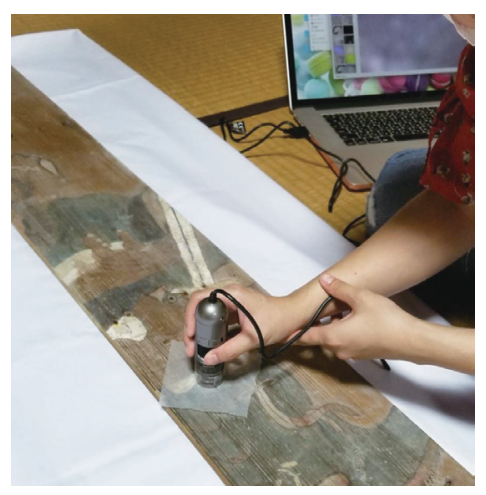

Figure 22. Painting of Shōki (photography setup). Photographs were taken using the electron microscope with a focus on areas where color could be seen. Photograph collection of Chie Kyan. Permission of Ishigaki City Board of Education. 


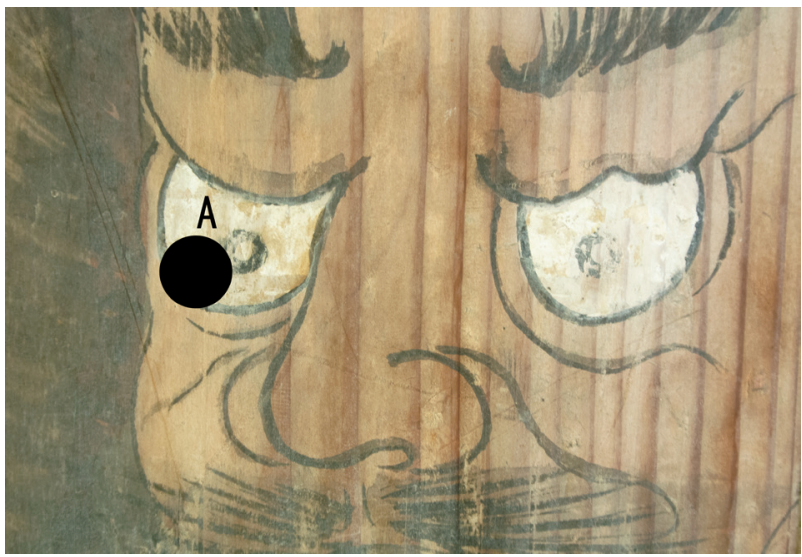

Figure 23. Painting of Shōki (detail). Photograph of the whites of Shōki's eyes. Photograph collection of Chie Kyan. Permission of Ishigaki City Board of Education.

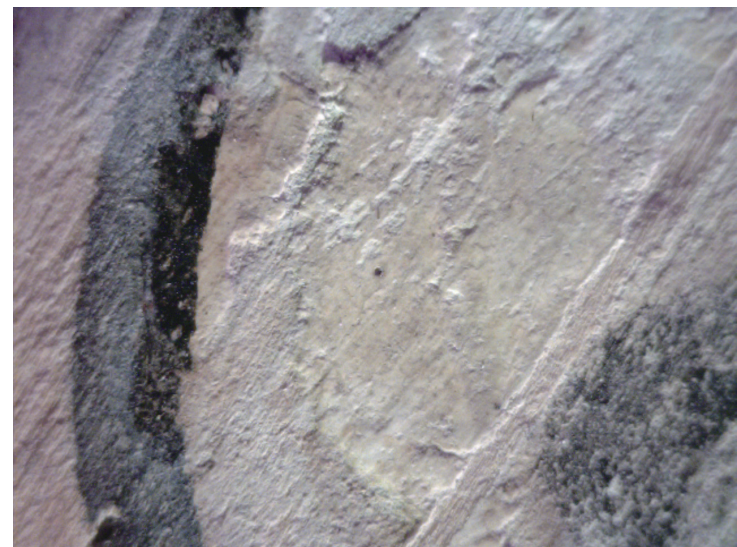

Figure 24. Electron microscope photograph, area A ( $\times 39$ magnification). Photograph by Yūki Taira. Permission of Ishigaki City Board of Education.

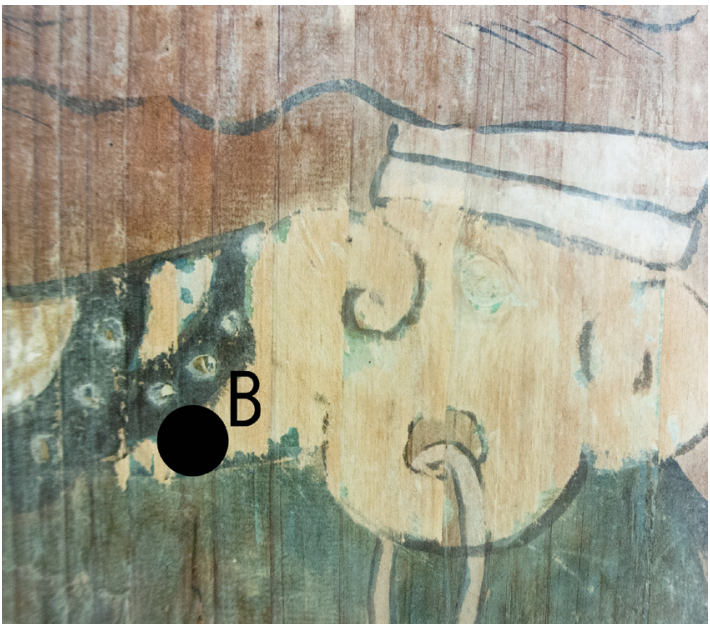

Figure 25. Painting of Shōki (detail). Photograph of a portion of Shōki's belt. Photograph collection of Chie Kyan. Permission of Ishigaki City Board of Education.

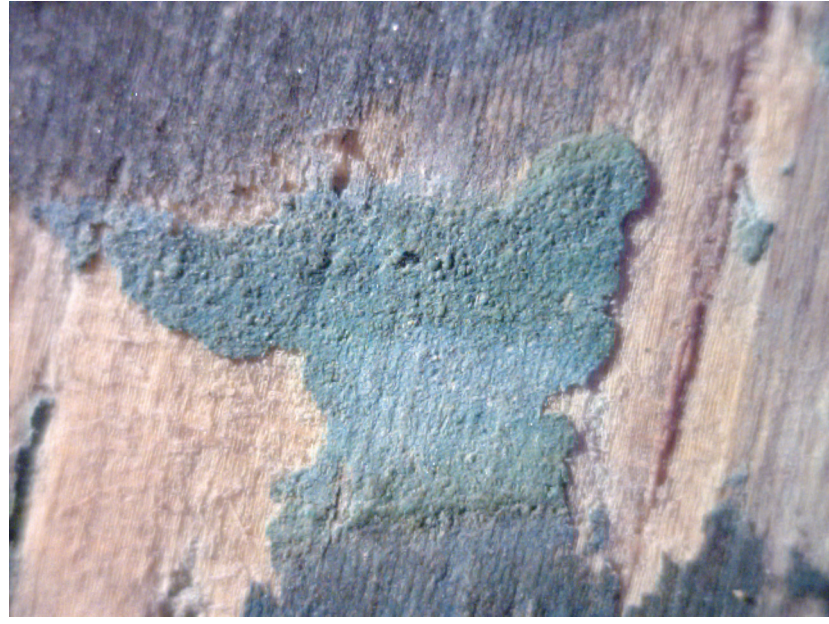

Figure 26. Electron microscope photograph, area B (x39 magnification). The presence of blue mineral pigment particles was confirmed.

Photograph by Yūki Taira. Permission of Ishigaki City Board of Education. 


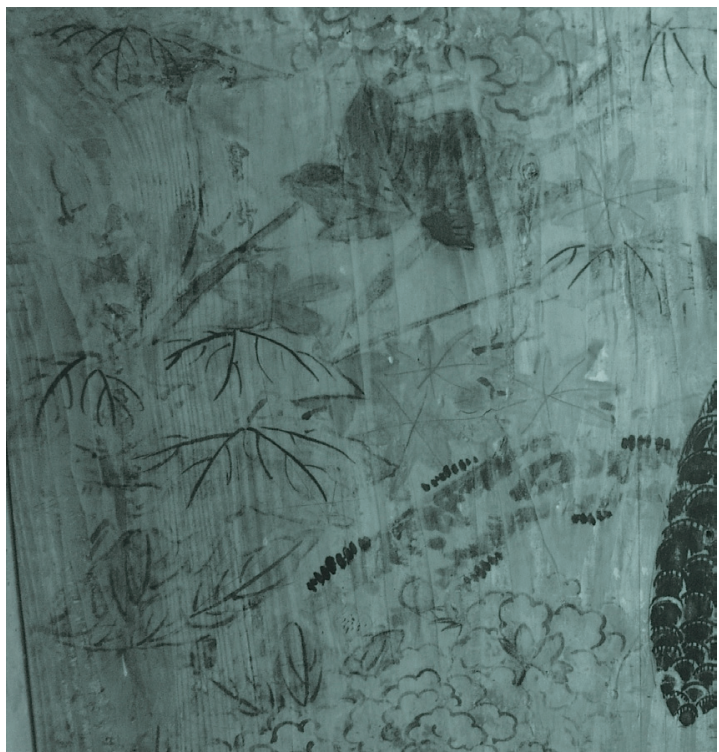

Figure 27. Painting of a hawk, a (detail). Infrared photography. Photograph by Tōma Takumi. Permission of Ishigaki City Board of Education.

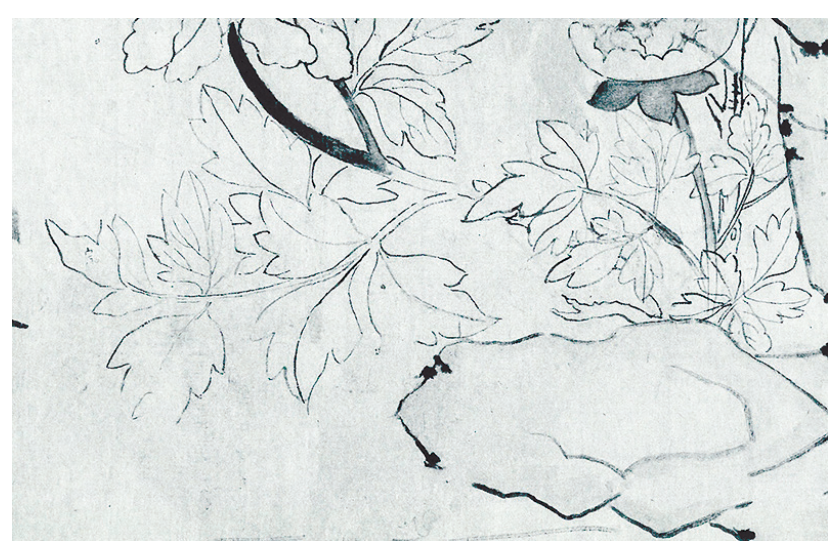

Figure 28. Kyūna Anshin. Peonies (detail). From Ishigaki-shi Yaeyama Hakubutsukan, Yaeyama kuramoto eshi gakōshū, p. 1.

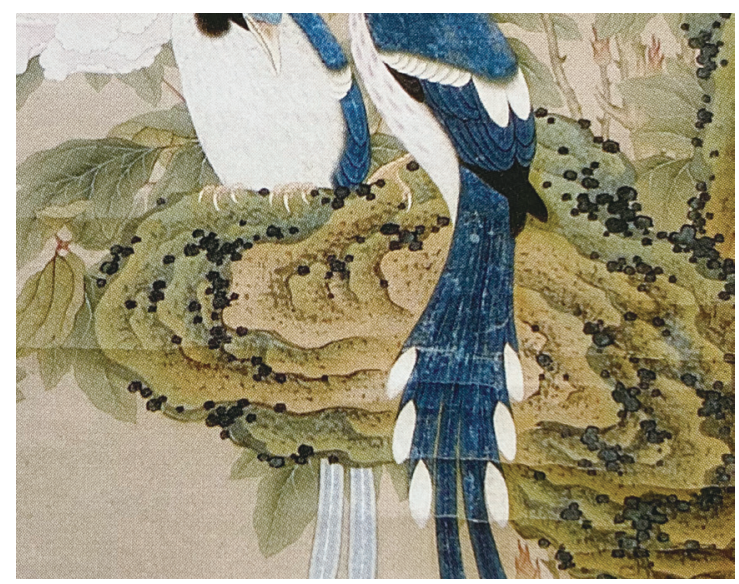

Figure 29. Mō Chōki. Painting of Peonies and Long-Tailed Chickens (inverted detail). Collection of the Okinawa Churashima Foundation, with permission.

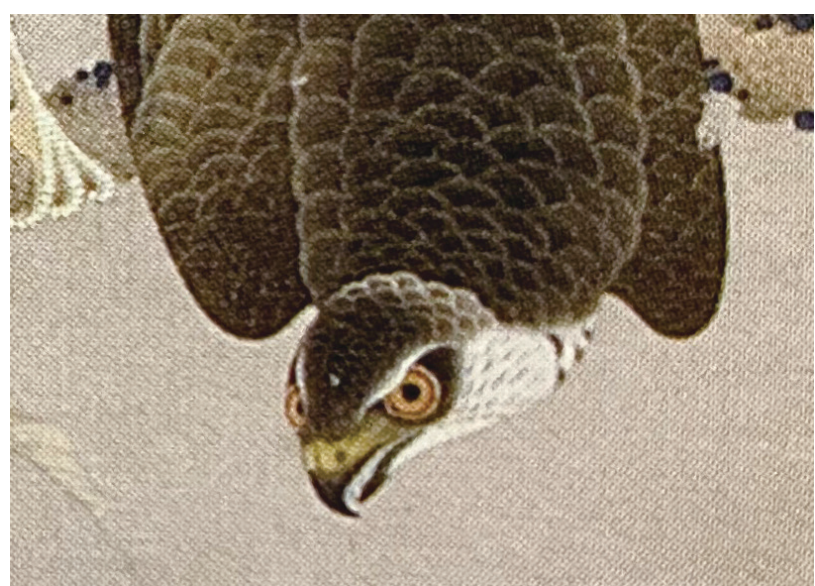

Figure 30. Mō Chōki. Painting of Hawk and Sparrows on an Old Hibiscus Tree (inverted detail). Collection of the Okinawa Churashima Foundation, with permission. 